\author{
Светозар Бошков \\ Универзитет у Новом Саду, Филозофски факултет \\ Одсек за историју, Нови Сад \\ e-mail: svetozarboskov@ff.uns.ac.rs \\ Борис Стојковски \\ Универзитет у Новом Саду, Филозофски факултет \\ Одсек за историју, Нови Сад \\ e-mail: boris.stojkovski@ff.uns.ac.rs
}

\title{
НЕКИ АСПЕКТИ ПРОУЧАВАЊА РЕЛИГИЈЕ У РАДОВИМА АНИЦЕ САВИЋ РЕБАЦ
}

Аnстракт: У богатом научном опусу Анице Савић Ребач значајно место заузима проучавање религије. Аница Савић Ребаи је проучавала различите религије, као и међусобне утииаје и прожимања античке религије и философије са другим религијама. У раду ће се посебна пажюа посветити неким аспектима проучавања религије код Анице Савић Ребаи, а нарочито ће се анализирати хришћанство, богумилство и кабала. У вези с тим посебно ће се обратити пажьа на њено дело Платонска и хришћанска љубав и приказ књиге В. Рибара Проблем историјске улоге хришћанства. Богумилство и кабалу Аница Савић Ребаи је проучавала у контексту Његошеве Луче микрокозма, за коју је била цењен и признат стручњак. На овај начин настојаћемо да дамо један новији поглед на ову врло комплексну тему у научном стваралаштву Анище Савић Ребац.

Кључне речи: Аница Савић Ребач (1892-1953), религија, хришћанство, кабала, богумилство.

Аница Савић Ребац (4. октобар 1892 - 7. октобар 1953) наш је чувени класичар, преводилац, философ, есејиста, историчар, песник, која је својим научним делом обезбедила место међу великанима српске науке. У свом богатом научном опусу, ${ }^{1}$ Аница Савић Ребац се дотицала, иако истина у мањој мери, различитих питања из области изучавања религије, а у овом раду ћемо представити њене погледе на историју хришћанства, богумилства и кабале.

Хришћанство је једна од најраспрострањенијих религија света. О њој је, наравно, написано мноштво књига и расправа. Ипак, Аница Савић Ребац није у свом целокупном делу посветила много пажње ни хришћанству а ни историји средњег века, тако да данас немамо њену студију која говори уопште о историји хришћанства или историји хришћанске религије. Њене идеје и погледе о хришћанству и хришћанској вери можемо

1 Библиографију радова Анице Савић Ребац израдили су Марија Јованцаи за период од 1905. до 1997. године и Мирјана Д. Стефановић за период од 1998. до 2013. године; Јованцаи 1997; Стефановић 2014. 
да видимо у приказу књиге марксистичког философа Вељка Рибара Историјска улога хришћанства у смени друштвено-економских формација, ${ }^{2}$ као и у њеном есеју Платонска и хришћанска љубав. ${ }^{3}$

Приказ књиге Вељка Рибара је доста критички. Аница Савић Ребац улогу хришћанства и његов однос према ропству посматра са искључиво марксистичког становишта и користи марксистичка уопштавања. Она се не слаже с основном поставком и идејом водиљом Вељка Рибара да је хришћанство подржавало прелазак са робовласничког на кметовски (феудални) систем и износи још неколико врло начелних, као и озбиљних методолошких примедаба на ову књигу. Међутим, Аница Савић Ребац у тексту не одбацује тезе Карла Маркса и Фридриха Енгелса да се хришћанска религија саживљавала са ропством током свих векова. Ниједног тренутка не одбацује ни другу тезу да је права улога хришћанства била у одржавању статичности сочијалног стања, као ни то да се хришћанство тобож удружило са капитализмом против социјализма. ${ }^{4}$

Овом приликом нас занима само први део ове тезе, као и став Анице Савић Ребац према историјској улози хришћанства у односу на ропство. Наиме, однос хришћанске цркве (испрва јединствене, а потом и подељене) комплексан је и амбивалентан. Црква, као живи организам, настајала је и развијала се столећима и представља једну врло сложену целину. Хришћанска црква је прихватила постојање ропства и стала у очување свеукупног поретка, али је током столећа сопственог развитка подржавала ублажавање односа према робовима. Неспорно је да су клерици и на Истоку и на Западу, високи црквени достојанственици, манастири, па и римске папе, поседовали робове. Било је и знаменитих црквених отаца који су оправдавали ропство као институцију. Чак ни свеукупан епископат није увек имао уједначен став према овом питању. Међутим, никако се не може генерализовати однос хришћанске цркве према ропству. Даћемо само неколико примера који илуструју погрешност горе изнесене тезе.

Један од најранијих хришћанских сабора, у Елвири 305/6. године, казнио је једну жену која је свог роба тукла до смрти. И други сабори у Византији су посебно штитили робове, и то поглавито жене, од насртљивих господара. Осамдесет и седми канон Трулског сабора, примера ради, наређује да се власник који има непримерен однос са робињом батина, а ако неко има однос са туђом робињом, треба да плати 36 номизми њеном власнику или ако је сиромашан да се батина. Управо у позноантичком периоду постоје и примери светаца који су помагали и лечили робове. Свети Теодор из IV века се наводи као заштитник робова. Житије Светог Теодора Сикејског је још један занимљив извор за ропство у Византији крајем VI и почетком VII столећа. Он је лечио многе робове и робиње, између осталог и робињу једног ђакона. Свети Јован Милостиви, александријски патријарх, откупљивао је и ослобађао робове које су Персијанци 614. године одвели у Ктесифон. У доба византијског василевса Василија Македонца (867-886) живела је и деловала Света Марија Млада, чије житије сведочи да се према робовима опходила као према члановима своје породице. Свети Василије Нови је такође излечио једну робињу. ${ }^{5}$

Познати су из извора и другачији ставови цркве, који забрањују ропство. На пример, Теодор Студит, игуман Богородичиног манастира Студион, у бројним документима овог цариградског манастира из 826. и 842. године изричито је забрањивао

2 Савић Ребац 1988a, 91-97.

3 Савић-Ребац 1988б, 23-37.

4 Савић Ребац 1988a, 92-94.

5 Hadjinicolaou-Marava 1950, 21-22; Хрıбт́vo 1985, 33-51; Rotman 2004, 191-192; Стојковски 2011, 470-471. са литературом. 
поседовање било робова за пољопривреду, било за личну употребу. За њега је то опасно за душе, али и супротно религији и позиву монаха. ${ }^{6}$ И типик Светог Атанасија Атонског за манастир Велику Лавру на Атосу (Светој Гори), донет 973-975. године, такође прописује забрану држања робова у овој монашкој заједници. ${ }^{7}$

Доба Комнина показује промењена гледишта у држави. У својој новели из 1095. године византијски василевс Алексије I Комнин каже како жали зато што не може да промени уврежено стање и истиче да међу људима постоји неправда противна хришћанству, али он нема моћ да промени већ постојеће устројство. За њега су робови били људска бића која такође треба да славе божански закон. Овај византијски аутократор је овом својом новелом наредио да и робови морају да буду венчани пред свештеником. Ово је значајна новина, јер у ранијим временима нису признавани нити брак нити породица робова и робиња. Сходно овој новели Алексија I Комнина, ако би роб уз два или три сведока доказао да је слободан човек, бивао би ослобођен. Да се постепено мењао положај робова у Византији сведочи и то што је унук поменутог цара Алексија I, Манојло I Комнин, био последњи цар који је доносио законске одредбе у вези са робовима откупивши у Цариграду њихову слободу, позивајући се на хришћанску веру. ${ }^{8}$

Попут црквених великодостојника у Византији, и уопште у православљу, и римокатолички клер је охрабривао чињење добрих дела и саветовао ослобађање заробљеника. У Западној Европи је од раног средњег века било низ сабора и одлука који су охрабривали ослобађање робова. Несумњиво, трговина робовима није замирала. Напротив. Али исто тако, овакве одлуке сведоче да став цркве није био искључив, нити исти током столећа. Црква је на Западу још од времена варварских краљевина пружала азил одбеглим робовима. О томе су расправљали сабори у Орлеану (који је сазвао први франачки краљ Хлодовех и где се први пут водила расправа о азилу) 511, 538. и 549. године, као и концил у Епону. Сабор у Арлу још 452. године, затим визиготски сабори у Толеду 589. и 633. године, и други сабори током V и VI столећа донос бројне одлуке о ослобођеницима. Папа Гргур Велики је ослободио све робове римске цркве. Бискупи су и у Француској, по меровиншком законодавству, и у Шпанији могли да ослободе робове. Сабори у Севиљи (590), Толеду (633) и Мериди (666) строго забрањују да бискуп робове које ослободи са црквених поседа задржи на својим приватним добрима. Правило Светог Фереола допушта и опатима манастира да ослобађају робове са акламацијом међу братством или без ње. Црква се бавила браком слободних људи и робова, као и одмарањем робова недељом и празницима. Поред сабора у Француској, о робовима је 691. године расправљао чак и сабор у Весексу. Црквени сабор у Шалону на Сони, одржан између 644. и 650. године, донео је одредбе у смислу спречавања трговине робовима ван краљевства. Штавише, упркос амбивалентном ставу цркве, у средњовековној Француској постојао је Ред Најсветијег Тројства, а у Шпанији Ред наше Госпе Милости Откупитељице (Свете Марије Мерцедес) који је основао Педро Ноласко. Ови редови су, поред класичних завета монашких редова, имали и један додатни - ослобађање хришћанских робова из муслиманског ропства. Током XIII и XIV века ови редови су откупљивали много хришћанских невољника. ${ }^{9}$ Очигледно је да је проблем ропства

6 Thomas, Constantinides Hero 2000, 71, 76-77, 85-86.

7 Thomas, Constantinides Hero 2000, 247, 249. Наравно, то не значи да је пракса држања робова ишчезла; напротив, поједини манастири су поседовали робове, али видимо да то ипак није била општа пракса, нити неко чување статичности феудалног поретка.

8 Nov. Post Just, 4, 35; Rotman 2004, 258-259; Köpstein 1980, 160-172; Hadjinicolaou-Marava 1950, 26 27.

9 О односу цркве и ропства уп. детаљније Стојковски 2008, 334-348. 
постојао у целој хришћанској Европи и да питање ропства није било могуће лако решити. Скоро сваки црквени сабор, поред својих основних проблема, решавао је и питања у вези са ропством.

О хришћанској религији код Анице Савић Ребац читамо и у студији Платонска и хришћанска љубав. Она у овој студији одаје признање хришћанству на унапређењу појма љубави и ту љубав посматра искључиво из аспекта платонизма. У овој студији она тражи и налази платонско порекло мисли водиље у химни љубави Светог апостола Павла, ${ }^{10}$ која одсликава хришћанско поимање љубави којом човек воли Бога и све људе, без обзира на то да ли су му пријатељи или непријатељи, а у корену ове ранохришћанске мисли стоји Платонов ерос који чини основу мистичке и философске љубави. Према

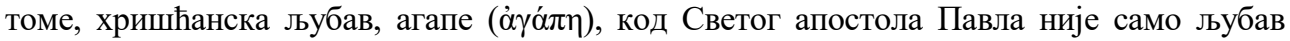
према Богу и свим људима него је и мистичка снага душе помоћу које човек спознаје Бога, и, како каже Аница Савић Ребац, која води пред Бога „лицем у лице“ и доводи до мистичног спајања душе са Богом пре смрти. ${ }^{11}$ Ипак, агапе је у првом реду божанска љубав, а код људи, она је духовни дар који их повезује међусобно и, путем Сина Божјег, са Богом. Види се да она хришћанску љубав сматра преузетом готово потпуно из хеленске мисли, а њену улогу доживљава као чудесни препород платонизма, ${ }^{12}$ и у томе је њен специфичан поглед. Редак је помен појединих византијских писаца, црквених отаца или мислилаца, попут Дионисија Ареопагита, и то увек у контексту философије и мистике. Њу не занимају ни византијски неоплатоничари нити хришћански писци који су се бавили антиком. Њено интересовање се своди само на преузимање платоновских идеја у неоплатонски философски систем. ${ }^{13}$ Сва византијска култура спој је и прожимање хеленистичке културе и хришћанства, али она о томе не пише. То је могуће објаснити и њеном идејом да је еволуција хришћанства углавном у прихватању хеленизма. Она је сматрала да су тек ренесансни писци достигли врхунац античке мисли. Још је једна опсервација овде могућа. Хришћанство она своди на једну појаву, а не на религију, која је ударила печат свеукупној цивилизацији и која је, штавише, сачувала, заједно са исламом, античку културу. И њен навод да је хришћанство преузело семитску представу о вансветском Богу ${ }^{14}$ би захтевао посебан осврт.

Када пише о богумилству, Аница Савић Ребац показује своју ерудицију и своје енциклопедијско знање. Богумилство тумачи кроз готово сву до њеног времена доступну литературу и изворе. Средњовековни феномен дуалистичких учења, њој битан због Његоша, Аница обрађује са више научности и мање спекулативности у односу на питање хришћанства. То се најбоље види у њеном делу $O$ народној песми „Цар Дуклијан и Крститељ Јован“.15 У овој епској песми Аница Савић Ребац тражи дуалистичке елементе као и пре ње многи наши, руски и бугарски стручњаци, од Илариона Руварца, Веселина Чајкановића, Милана Будимира, преко Веселовског и Драгоманова. Њено тумачење ове народне песме показује сву комплексност богумилског учења, али и дуализма уопште. Аница Савић Ребац у богумилским елементима ове песме тражи

101. Kop. $1,13$.

11 Савић-Ребац 1988б, 27-28.

12 Савић-Ребац 1988б, 37.

13 Савић-Ребац 1988б, 25-27. О много комплекснијем односу византијских неоплатоничара према Платоновој философији сведочи обимна литература из које издвајамо само неколико наслова на страним језицима: Rosan 1949; Masai 1956; Blumental and Markus, 1981; Lloyd 1990; Bargeliotes 2000; на српском језику уп. Бајервалтес 2009; Лаут 2009.

14 Савић-Ребац 1988б, 25. Иако је инкарнација Христа на Земљи у хришћанству показатељ Божијег присуства међу људима.

15 Савић-Ребац 1988ц, 349-371. 
трагове манихејства и гностицизма, али остаје уздржана према изворима који су могли утицати на богумилство, као и на правце из којих су ти утицаји и улазили у богумилску доктрину. ${ }^{16}$

Њен поглед на епску песму Цар Дуклијан и Крститељ Јован веома је вредан допринос проучавању богумилског елемента у фолклору код јужнословенских народа, доста редак у нашој науци. Вреди истаћи овде рад и Вере Антић, која је богумилске елементе обрађивала у македонском фолклору. ${ }^{17}$ Овом приликом нас највише занима однос Анице Савић Ребац према овој врло комплексној теми. Она наглашава сложеност богумилског дуализма и истиче одређена одступања у богумилској доктрини у односу на манихејство. Према мишљењу Анице Савић Ребац, Мани је у своје учење увео два радикално одвојена принципа у дуализму. ${ }^{18}$ Она спада у скупину аутора који су богумилство више и ближе везивали за манихејски корен. Поред Анице Савић Ребац, као без сумње великог ауторитета на пољу философије, класичних наука и науке о књижевности, посматрање богумилства у ширем контексту дуалистичких учења кроз историју карактеристично је и за дела таквих медиевиста светског гласа какви су Стивен Рансимен ${ }^{19}$ или Димитри Оболенски. ${ }^{20}$ Овог потоњег и Аница Савић Ребац цитира. ${ }^{21}$ Штавише, Оболенски хеленски мит о души која је заточена у материјалном свету сматра макар имплицитним кореном сваког дуализма. ${ }^{22}$

Занимљиво је приметити и да у својим анализама богумилства и њиховог учења Аница Савић Ребац не помиње босанске крстјане ни цркву босанску, иако је манихејство имало, према неким претпоставкама, значајан утицај на развој њиховог учења. ${ }^{23}$ Богумили у Србији спомињу се само узгредно, бабуни и патарени ни толико. Њу богумилство занима као философско-религијска појава, у контексту манихејског учења, и уопште дуалистичких доктрина.

Богумилство је Аници Савић Ребац био ванредно важан елемент у њеном изучавању Петра Петровића Његоша и његове Луче микрокозма. Она у овом делу тражи различите мистичне утицаје, међу којима у првом реду богумилско и кабалистичко. У

16 Савић-Ребац 1988ц, 362-371.

17 Антиќ 1982, 113-126.

18 Савић-Ребац 1988ц, 352-354. Мада ни сам манихеизам не одваја радикално два принципа, и ту су катари, донекле павликијанци, па чак и Драговићка црква, били строжи, што примећује и Аница Савић Ребац. Најважнији извор који документује овакву тврдњу јесте Августин и његово дело Contra Faustum, где Фауст детаљно објашњава манихејски дуализам, али на концу не одвајајући радикално два принципа, Бога и hyle односно материју (Aug. Contra Faustum, XXI). В. Савић-Ребац 1988ц, 354; уп. и Alić 1982, 173. в. и нап. 67; Драгојловић 1987, 193-194, уп. нап. 24 за попис извора. О Августиновом делу као извору за хришћанско-манихејске распре уп. Lim 1995, 96-98.

19 Runciman 1982. уп. нарочито 5-181. Могуће је пратити велику сличност у Рансименовом излагању, од гностицизма, преко манихејства до богумила и катара, са писањем Анице Савић Ребац, с тим што Рансимен хеленску мисао и њен утицај на дуализам готово и не спомиње.

20 Obolensky 2009, 13-286 нарочито. Важна је тврдња Оболенског да је немогуће историјски наћи везу између гностицизма, манихејства, као и бројних јереси које су настајале све до VIII века. Obolensky 2009, 33.

21 Савић-Ребац 1988ц, 351, нап. 6.

22 Obolensky 2009, 16.

23 Alić 1982, 172-184. У наставку свог дела, Алић покушава да докаже да су крстјани, односно верници цркве босанске дошли у додир са манихеизмом преко Угарске. То је мало вероватно, јер богумила у Угарској нема, судећи по изворима, после 1046, а Халисије, Печенези и други народи које Алић набраја су муслимани, в. Стојковски 2010, 171-178; Bálint 2013, 501-523. У новије време се појављују истраживања која негирају дуализам цркве босанске, в. Mužić 2008, 65-67. Нажалост, не знамо став Анице Савић Ребац према овом питању. 
свом спису Његош и богумилство Аница Савић Ребац више истиче разлике изворног манихејства с једне и катарског и богумилског неоманихеизма, како их назива, с друге стране. Знатно јасније него у претходно описаној расправи о епској песми Цар Дуклијан и Крститељ Јован, катаре и делимично византијске богумиле она назива радикалнијим дуалистима, у односу на богумиле, па и на само Манијево изворно учење. Примећује и да у манихејству пад Прачовека у материјално (смртно) нема карактер огрешења, односно примордијалног греха. ${ }^{24}$

Кабала, јеврејска традиција, односно током векова јеврејска езотерија и мистика, била је такође један од предмета изучавања религије Анице Савић Ребац. Овом проблематиком она се бавила у свом спису Његош, кабала и Филон. Овај рад је занимљив из много аспеката. Наиме, Аница Савић Ребац у Лучи микрокозма налази различите кабалистичке утицаје, којих нема много, и покушава да делове овог Његошевог спева повеже са кабалистичком мишљу, како директно (она сматра из усмених Његошевих сазнања), тако и преко Игоа, Гетеа, раног Хегела, Милтона и других писаца или философа. Литература о кабали је поглавито немачка. Говорећи о кабали, Аница Савић Ребац се осврће и на различите утицаје у јеврејској мистици. Помиње и утицај античке философије, јеврејског неоплатонизма, као и оријенталних и гностичких струја. ${ }^{25}$

О вези различитих источњачких учења, па и манихеизма, и данас се доста пише у стручној и научној литератури. Јеврејска је традиција претрпела знатне утицаје манихеизма, апокрифних списа (попут Кюиге Енохове, Къиге Сетове и сл.), а сиријскомесопотамска гностичка учења имају значајан утицај и на формирање позноантичке и раносредњовековне јеврејске мисли, једнако као што и јудаистичка библијска егзегеза има значајан утицај и на манихејство, па чак и на неке класичне дуалистичке списе из Наг Хамади корпуса манихејских текстова. ${ }^{26}$

Познавање кабале, као и међусобни утицаји ове јеврејске традиције и хеленске философије, као и Филона Александријског, представљају значајан сегмент проучавања Његошеве Луче код Анице Савић Ребац. ${ }^{27}$ Она одлично познаваје историју кабале, као и њен средњовековни развој, нарочито развој кабалистике код Јевреја Провансе у XIII веку. Међутим, њен поглед на катарски утицај на кабалу део научника који се баве кабалом не види на исти начин. Наиме, постоји мишљење да су провансалски кабалисти познавали катарску доктрину због свог дуализма. Не треба одбацити ни сличност њихових учења о сељењу душе, па ни постојање аскетског братства међу проучаваоцима кабале који су живели аскетски и потпуно се посвећивали изучавању Торе, притом одбацујући све овоземаљско. ${ }^{28}$

На поимање кабале Анице Савић Ребац и јеврејске традиције, па и јеврејске езотерије и мистике уопште, пресудан утицај имао је Гершом Шолем. У време када се бавила Лучом микрокозма (крајем 30-их година XX века), Аница Савић Ребац имала је више личних контаката с овим утемељивачем савремене науке о кабали, значајним јеврејским мислиоцем, који је у то време био и професор универзитета у Јерусалиму. ${ }^{29}$ Гностичка, па и античка грчка философија су, по Шолему и Аници Савић Ребац, имале

24 Савић-Ребац 1966а, 120-121. Уп. Runciman 1982, 14; Obolensky 2009, 17-18.

25 Савић-Ребац 1966б, 131-151, посебно 140-141.

26 Reeves 1996, 5-212. Библијски јудаизам, посебно Кғьга Постағьа, имали су, према Ривсу, и кључан утицај на манихејску козмогонију. В. његову студију Reeves 1997. О кабалистичком тумачењу Постана в. Smith 2010, 11-137.

27 Савић-Ребац 1966б, нарочито 143-145.

28 Савић-Ребац 1966б, 134-135, в. Gečel 1987, 79, нап. 6.

29 Савић-Ребац 1966б, 133. 
значајан уплив на кабалистичка поимања, штавише, Гершом Шолем поједина кабалистичка учења настала у Прованси током XIII века и назива гностичка. Треба рећи да поједина Шолемова гностичка проучавања кабале имају опоненте у науци. Гностичка кабала се коначно јавља тек у Херони, у Каталонији, у другој половини XIII века, и тек тад се јавља и одређени дуализам, а питање зла постаје видљивије постављено. ${ }^{30}$

Идеје и везе Његошевог спева Луче микрокозма са кабалом проучаване су и пре Анице Савић Ребац. Перо Слијепчевић се такође бавио утицајем кабале на Његоша. Аница Савић Ребац је систематизовала та проучавања и дала особен печат његошологији, нарочито овом аспекту проучавања Луче микрокозма и утицаја на цетињског владику и писца. И она, као и многи други проучаваоци Његошевог дела, сматра да је до додира са кабалом дошло индиректно, мада, неки извор који то потврђује, за сада не постоји. ${ }^{31}$

Аница Савић Ребац и њено проучавање Његошеве Луче микрокозма оставили су велики и значајан утицај на науку о књижевности, философију, историју и философију религије и друге науке све до данас. Њени религијски аспекти, пре свега богумилство у овом Његошевом спеву, и данас научнике који се баве делом великог српског песника надахњују на различита промишљања и на тражење дубљих философских корена у античкој философији, богумилству или кабали. Управо на трагу Анице Савић- Ребац и у својој новој књизи, француски писац и историчар књижевности српског порекла Борис Лазић пише о гностичким, тачније дуалистичким, богумилским, односно манихејским утицајима код Његоша, упливу философије Платона, па и Оригена. ${ }^{32}$

Религија и њено проучавање у уистину ванвременском опусу Анице Савић Ребац заузимају посебно место. Интердисциплинарни приступ, који је красио енциклопедијско знање које је она имала, и у изучавању религије био је основна карактеристика радова Анице Савић Ребац. Ни њена лична убеђења, па ни идеолошка матрица којој је и сама припадала, нису недостајала и дала су печат њеним истраживањима у овом домену. Треба знати да она није била историчарка, да су њени погледи више философски, али да то никако не значи да Аница Савић Ребац није оставила значајан траг и у проучавању историје религије, напротив. Управо њена мултиперспективност, њено вишезначно тумачење античких и средњовековних религијских учења и појмова подстичу на размишљање и представљају један особити светоназор једне од најученијих жена модерне српске науке.

30 Општи преглед историје кабале (нарочито средњовековне) у Encyclopedia Judaica, second edition, Volume 11 Ja-Kas, ed. in chief Fred Skolnik, Detroit, 2007, 590-599, 602-610 (Kabbalah); о кабалистици Гершома Шолема уп. његова дела Scholem 1962; Scholem 1974. О Шолемовом схватању кабале в. Biale 1982, 35-93; Weidner 2003. О различитим тумачењима неких Шолемових претпоставки и опонирању истим Gečel 1987, 35-39, 94-95.

31 Петровић Његош 1968. Нарочито уп. Флашар 1968, 119-147, као и предговор Савић-Ребац 1968, 5-48; од литературе в. Слијепчевић 1950, 150-152; Lux 1982, 128-130; Радуловић 2007, 532-538.

32 Lazić 2009, књига у штампи, 63-69. Овом приликом аутори исказују своју најдубљу захвалност драгом колеги и пријатељу др Борису Лазићу на својевременом уступању рукописа књиге која је у припреми за штампу. Пагинација је извршена према рукопису који нам је уступио колега Лазић. 


\section{Извори и литература}

Антиќ, Вера (1982): „Дуалистички елементи во македонскиот фолклор“, Богомилството на Балканот во светлината на најновите истражувања, Материјали од симпозијумот одржан во Скопје на 30, 31 мај и 1 јуни 1978 година, Скопје: Македонска академија на науките и уметностите, 113-126.

Бајервалтес, Вернер (2009): Платонизам у хришћанству, Нови Сад: Академска књига.

Лаут, Ендрју (2009): Извори хришћанског мистичног предања: од Платона до Псеудо-Дионисија Ареопагита, Београд, Сремски Карловци: Мартириа.

Петровић Његош, Петар II (1968): Луча микрокозма, Београд: Просвета.

Радуловић, Немања (2007): „Езотерични оквири Луче микрокозма“, Зборник Матище српске за књижевност и језик, 55-3, Нови Сад: Матица српска, 511-543.

Савић-Ребац, Аница (1988a): „Проблем историјске улоге хришћанства“, Студије и огледи I-II, Нови Сад: Књижевна заједница Новог Сада, 91-97.

Савић-Ребац, Аница (1988б): „Платонска и хришћанска љубав“, Студије и огледи I-II, Нови Сад: Књижевна заједница Новог Сада, 23-37.

Савић-Ребац, Аница (1988ц): „О народној песми Цар Дуклијан и Крститељ Јован“, Студије и огледи I-II, Нови Сад: Књижевна заједница Новог Сада, 349-371.

Нови Завет. (1998). Превод Комисије Светог архијерејског синода СПЦ. Београд: Свети архијерејски синод Српске православне цркве CAHУ.

Слијепчевић, Перо (1950): „Четири теме о Лучи“, Гласник САН II-1, Београд:

Стојковски, Борис (2008): Трговина робљем на Медитерану у средњем веку, магистарска теза.

Стојковски, Борис (2010): „Византијска црква и ропство“, Српска теологија данас, Београд: Институт за теолошка истраживања, Правни богословски факултет, 467477.

Стојковски, Борис (2010): „Правни положај муслимана у средњовековној Угарској“, Зборник радова Правног факултета 44/1, Нови Сад: Правни факултет, 171179.

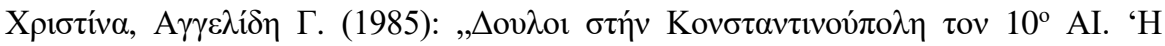

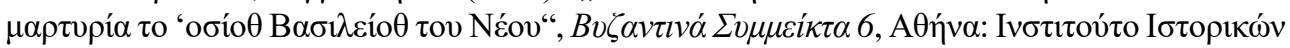

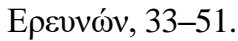

Alić, Salih H. (1982): „Bosanski krstjani i pitanje njihovog porijekla i odnosa prema manihejstvu“, Богомилството на Балканот во светлината на најновите истражувања, Материјали од симповијумот одржан во Скопје на 30, 31 мај и 1 јуни 1978 година, Скопје: Македонска академија на науките и уметностите, 153-194.

Bargeliotes C. Leonidas (2000): „Plethon's Conception of Cosmos and its impact on Western Cosmologica“, Zbornik Matice srpske za klasične studije 2, Novi Sad: Matica srpska, $37-51$.

Biale, David (1982): Gershom Scholem: Kabbalah and Counter-History, Cambridge: Harvard University Press.

Blumental, H. J. and Markus, R. Austin eds. (1981): Neoplatonism and Early Christian thought:Essays in honour of A. H. Armstrong, London: Variorum Publications.

Gečel, Rolan (1987): Kabala, Beograd: Novo delo.

Hadjinicolaou-Marava, Anne (1950): Recherches sur la vie des esclaves dans le Monde Byzantin, Athènes: Collection de l'Institut français. 
Idel, Moshe (2007): „Kabbalah“, Encyclopedia Judaica, 11, Ja-Kas, ed. Fred Skolnik, Detroit: Thomson Gale, 589-690.

Köpstein, Helga, (1980) „Zur Novelle des Alexios Komnenos zum Sklavenstatus (1095)", Actes du XVe Congrès international d'Etudes byzantines, IV Histoire. Communications, Athènes: Association Internationale des Études Byzantines, 160-172.

Lazić, Boris (2009): La relation du temps et de l'éternité dans l'œuvre poétique de Petar II Petrović Njegoš, doktorska disertacija.

Lim, Richard (1995): Public Disputation, Power, and Social Order in Late Antiquity, Berkeley: University of California Press.

Lloyd, A. C. (1990): The Anathomy of Neoplatonism, Oxford: Clarendon Press.

Misl.

Obolensky, Dmitri (2009): Bogumili. Studija o balkanskom neomaniheizmu, Zagreb:

Reeves, John C. (1996): Heralds of That Good Realm: Syro-Mesopotamian Gnosis and Jewish Traditions, Leiden: Brill.

Reeves, John C. (1997): Jewish Lore in Manichaean Cosmogony: Studies in the Book of Giants Tradition, New York: Hebrew Union College Press.

Rosan, Laurence Jay (1949): The Philosophy of Proclus: The Final Phase of Ancient Thought, New York: Cosmos.

Rotman, Youval (2004): Les esclaves et esclavage. De la Méditerranée antique à la méditerranée médiévale $V I^{e}-X I^{e}$ siècles, Paris: Les belles lettres.

Runciman, Steven (1982): The Medieval Manichee: A Study of the Christian Dualist Heresy, Cambridge: Cambridge University Press.

Schaff, Philip ed. (1956): Augustine: The Writings Against the Manichaeans and Against the Donatists, Nicene and Post-Nicene Fathers Series I, volume 4, Michigean: Grand Rapids.

Scholem, Gershom (1962): Ursprung und Anfänge der Kabbala, Berlin: De Gruyter.

Scholem, Gershom (1974): Kabbalah, New York: The Jewish Publication Society of America.

Smith, David Chaim (2010): The Kabbalistic Mirror of Genesis. Commentary on Genesis 1-3, Glasgow: Daat Press, 2010.

Ternovácz, Bálint (2013): „A bogumil eretnekség a XI. századi Magyar Királyság déli területein“, Fons XX, 4. sz., Budapest: Szentpétery Imre Történettudományi Alapítvány, 501523.

Thomas, John and Constantinides Hero, Angela eds. (2000): Byzantine Monastic Foundation Documents. A complete Translation of the Surviving Founders Typika and Testaments, Washington: Dumbarton Oaks.

Weidner, Daniel (2003): Gershom Scholem. Politisches, esoterisches und historiographisches Schreiben, München: Wilhelm Fink Verlag.

Zepos, Ioannes and Zepos, Panagiotes eds. (1931): Novellae et Bullae Aureae imperatorum post Justinianum, Jus Graecoromanum 1, Athènes: G. Felix.

Masai, François (1956): Pléthon et le platonisme de Mistra, Paris: Les Belles Lettres. 


\section{Svetozar Boškov \\ Boris Stojkovski}

\section{SOME ASPECTS OF THE RELIGION STUDIES IN THE WORK OF ANICA SAVIĆ-REBAC}

In the rich scientific opus of Anica Savić-Rebac the study of the religion occupies a significant place. Anica Savić-Rebac dealt with different religions, as well as mutual influences and permeations of ancient religions and philosophy with other religious teachings.

This paper examines the works of Anica Savić-Rebac dedicated to Christianity, bogomilism and kabbalah. She wrote on Christianity in her study about the Platonic and Christian love. Her views on the one of the most widespread world religions today were given through her review of the book written by V. Ribar on the problem of the historical role of the Christianity. She also studied bogomilism and kabbalah in the context of her studies on a famous $19^{\text {th }}$ century work entitled Luča mikrokozma, written by Petar II Petrović Njegoš, for which she was one of the most prominent experts. With a critical overview and an analysis of the works of Anica Savić-Rebac the authors give a newer approach to this very complex subject in her scientific production. 